\title{
KARAKTERISTIK MODA ANGKUTAN UMUM BERBASIS ONLINE DI JAKARTA SELATAN
}

\author{
Zahra Zakiyya Mustaqima, Imma Widyawati Agustin, Dadang Meru Utomo \\ Jurusan Perencanaan Wilayah dan Kota, Fakultas Teknik, Universitas Brawijaya \\ Jalan Mayjen Haryono 167 Kota Malang 65145 -Telp (0341)567886 \\ e-mail: zahrazak26@gmail.com
}

\begin{abstract}
ABSTRAK
Jakarta Selatan sebagai pusat permukiman dan pusat kegiatan ekonomi di DKI Jakarta, mengalami pertumbuhan penduduk setiap tahunnya yang mengakibatkan peningkatan berbagai kebutuhan, salah satunya adalah kebutuhan untuk mobilisasi yang ditunjang dengan adanya transportasi berupa kendaraan pribadi dan kendaraan umum. Seiring dengan berkembangnya teknologi, mulai diterapkan teknologi informasi pada angkutan umum sebagai solusi masalah kemacetan dan masalah angkutan umum konvensional. Penelitian ini bertujuan untuk mengetahui karakteristik dan perbedaan dari moda angkutan umum berbasis online di Jakarta Selatan. Analisis yang digunakan adalah analisis deskriptif. Berdasarkan hasil analisis, perbedaan karakteristik angkutan umum berbasis online tergantung pada perusahaan penyedia jasa. Perbedaan dari setiap perusahaan penyedia jasa angkutan umum berbasis online, yaitu negara asal dan cakupan layanan, jenis kendaraan yang digunakan, fasilitas pelayanan, metode pembayaran, fitur poin dan reward, jam sibuk, tarif angkutan sepeda motor dan mobil, serta biaya tambahan jika melakukan pembatalan.
\end{abstract}

Kata Kunci : Angkutan Umum Berbasis Online, Jakarta Selatan

\section{ABSTRACT}

South Jakarta as the center of residential and economic activities in Jakarta, experienced population growth every year. The increasing population of Jakarta Selatan resulted in an increase in various needs, such as the need for mobilization. The need for mobilization is supported by the transportation in South Jakarta in the form of private vehicles and public transportations. Along with the technology development, the information technology began to be applied in public transport as a solution to the problem of congestion and the problem of conventional public transport. The main purpose of this research is to determine the characteristics and differences of online-based public transportation is South Jakarta. This research use descriptive analysis. Based on the results of descriptive analysis, the differences of online-based transportaion depend on the service provider company. Differences from every online-based public transportation companies are origin country and service coverage, type of vehicle used, service facilities, payment method, point and reward features, peak hours, motorcycles and cars fare, as well as additional fees of cancellation.

Keywords: Online based public transportation, South Jakarta

\section{PENDAHULUAN}

Jakarta Selatan memiliki penduduk berjumlah 2.185.711 dan merupakan jumlah penduduk ketiga terbanyak dibandingkan dengan kota administrasi di DKI Jakarta lainnya (Provinsi DKI Jakarta dalam Angka Tahun 2017). Berdasarkan data Statistik Daerah Kota Jakarta Selatan Tahun 2016 yang terus bertambah setiap tahun dan salah satu penyebabnya karena Jakarta Selatan merupakan pusat permukiman, terutama permukiman kelas atas dan juga pusat kegiatan ekonomi di DKI Jakarta, seperti Sudirman Business District di Jalan Jenderal Sudirman, Kecamatan Kebayoran Baru. Banyaknya jumlah penduduk di Jakarta Selatan, baik yang merupakan penduduk asli Jakarta Selatan maupun penduduk pendatang dari daerah luar Jakarta Selatan menyebabkan bertambahnya kebutuhan masyarakat, salah satunya adalah kebutuhan akan pergerakan untuk beraktivitas, seperti bekerja, bersekolah, berbelanja, serta aktivitas lainnya.

Jumlah kendaraan pribadi yang terdapat di Jakarta Selatan, yaitu 1.784 .724 unit, sedangkan jumlah angkutan umum yang terdapat di Jakarta Selatan berjumlah 23.906 unit dan merupakan yang paling banyak di antara kota administrasi lain di DKI Jakarta (Jakarta Selatan dalam Angka 2016). Banyaknya jumlah kendaraan tersebut menimbulkan masalah kemacetan di beberapa jalan di Jakarta Selatan. Berdasarkan Data Penyebab Kemacetan di DKI Jakarta (Dinas Perhubungan, 2011) yang sebagian besar disebabkan oleh jalan yang sempit, lalu lintas padat, parkir di jalan, serta angkutan umum yang berhenti sembarangan. Jakarta memiliki rata-rata 33.240 kali kendaraan 
berhenti di jalan dalam satu tahun dan dikenal sebagai kota paling macet sedunia menurut Survey Castrol's Magnatec Stop-Start Index (Amajida, 2016). Kemacetan lalu lintas berdampak pada ketidakpastian dalam segi waktu dan biaya. Salah satu solusinya, yaitu angkutan umum.

Angkutan umum konvensional masih memiliki beberapa permasalahan, seperti tidak adanya jadwal yang tetap, pola rute yang memaksa terjadinya transfer, penumpang yang berlebih saat jam sibuk, jaminan keamanan dalam transportasi umum, kondisi internal dan eksternal yang buruk, serta cara mengemudikan kendaraan yang sembarangan (Amajida, 2016). Permasalahan lainnya, yaitu sering dilakukannya pemberhentian angkutan yang tidak pada tempatnya, serta terlalu lama berhenti atau ngetem untuk menunggu penmpang (Anindhita, 2016). Munculnya angkutan umum berbasis online menjadi salah satu solusi permasalahan kemacetan dan angkutan umum konvensional.

Angkutan umum berbasis online dapat diartikan sebagai perpindahan barang atau orang dari satu tempat ke tempat lain dengan menggunakan kendaaan yang terkoneksi atau terhubung ke jaringan internet (Wijaya, 2016). Terdapat beberapa jenis angkutan umum berbasis online, yaitu angkutan sepeda motor dan angkutan mobil. Angkutan sepeda motor berbasis online disebut ojek yang merupakan sarana angkutan umum bermotor roda dua yang disediakan untuk digunakan oleh umum dengan memberikan sejumlah biaya atau ongkos tertentu sebagai bayaran terhadap layanan jasanya atas dasar kesepakatan bersama (Bahar dan Tamin, 2010). Angkutan mobil berbasis online atau biasa disebut taksi onlne, yaitu angkutan dengan menggunakan angkutan umum yang diberi tanda khusus dan dilengkapi dengan argometer yang melayani angkutan dari pintu ke pintu dalam wilayah operasi yang terbatas (Keputusan Menteri Perhubungan Nomor 35 Tahun 2003). Penggunaan teknologi informasi dalam angkutan umum memberikan kemudahan bagi para penggunanya, seperti kemudahan dalam mengakses aplikasi yang dapat diunduh di smartphone para pengguna dan juga kemudahan dalam melakukan apapun yang diinginkan oleh pengguna, seperti pengiriman barang, pesan antar makanan, berbelanja, serta bepergian.

Karakteristik angkutan umum berbasis online menurut Wijaya (2016), antara lain:

1. Perusahaan pengangkutan umum online, seperti Go-Jek, Uber Taxi, Grab Bike, dan sebagainya menyelenggarakan usaha jasa pengangkutan orang dan/atau barang melalui media elektronik dengan memungut bayaran atau tarif kepada penumpang.

2. Adanya sintesis antara metode pengangkutan konvensional dengan metode transaksi yang bersifat elektronik. Metode pengangkutan konvensional di sini, yaitu sama dengan angkutan umum lainnya, sehingga terdapat waktu tunggu penumpang, namun dengan adanya perpaduan teknologi, penumpang mampu melacak lokasi pengendara dan juga bisa melakukan transaksi lewat online.

3. Penggunaan dokumen elektronik sebagai dokumen bukti pengangutan barang, di mana setiap informasi elektronik yang dibuat, diteruskan, dikirimkan, diterima, atau disimpan dalam bentuk analog, digital, elektromagnetik, optikal, atau sejenisnya, yang dapat dilihat, ditampilkan, atau didengar melalui komputer atau sistem elektronik, termasuk tetapi tidak terbatas pada tulisan, suara, gambar, peta, rancangan, foto atau sejenisnya, huruf, tanda, angka, kode akses, simbol atau perforasi yang memiliki makna atau arti atau dapat dipahami oleh orang yang mampu memahaminya.

4. Kegiatan usaha angkutan umum berbasis online, yaitu memberikan pelayanan atau jasa pengangkutan orang dan/atau barang kepada pelanggan dengan mekanisme secara online. Setiap pelayanan atau jasa yang diberikan oleh perusahaan angkutan umum berbasis online memiliki tarif atau ongkos tertentu, dan kewajiban pelanggan adalah membayar harga pelayanan atau jasa tersebut.

5. Kegiatan usaha yang dilakukan oleh berbagai perusahaan angkutan umum berbasis online menawarkan jasa, sehingga termasuk dalam kegiatan perdagangan atau perniagaan.

Perusahaan penyedia jasa transprortasi online saling bersaing dan melakukan inovasi untuk memuaskan penumpang. Para perusahaan penyedia jasa transportasi online melakukan inovasi dengan mengembangkan fitur yang ditawarkan selain jasa untuk pengangkutan orang (Chan et al., 2017). Setiap perusahaan penyedia jasa transportasi online juga memiliki jenis kendaraan yang berbeda untuk pengangkutan orang dan tarif yang berbeda setiap jenis kendaraanya (Fatuh \& Widyastuti, 2017). Perbandingan tarif mencakup tarif minimal penggunaan jasa angkutan, tarif per kilometer, tarif pada jam sibuk, serta biaya tambahan jika 
melakukan pembatalan pemesanan (Nurhidayah \& Alkarim, 2017).

\section{Ruang Lingkup}

Ruang lingkup wilayah yang dijadikan sebagai wilayah studi dalam penelitian ini adalah Kota Administrasi Jakarta Selatan. Wilayah tersebut dipilih karena Jakarta Selatan memiliki jumlah angkutan umum sebanyak 23.906 unit yang merupakan jumlah terbanyak dibandingkan dengan wilayah lainnya di DKI Jakarta dan juga jumlah kendaraan pribadi, yaitu 1.784.724 unit. Transportasi di DKI Jakarta, termasuk Jakarta Selatan sudah lebih lengkap dibandingkan dengan kota-kota lain di Indonesia, serta sudah banyak penggunaan teknologi informasi dalam pengoperasionalan sistem transportasi di Indonesia, khususnya transportasi umum seperti penggunaan teknologi pada busway, ojek, dan juga taksi di Jakarta Selatan. Gambar 1 menunjukkan peta ruang lingkup wilayah studi.

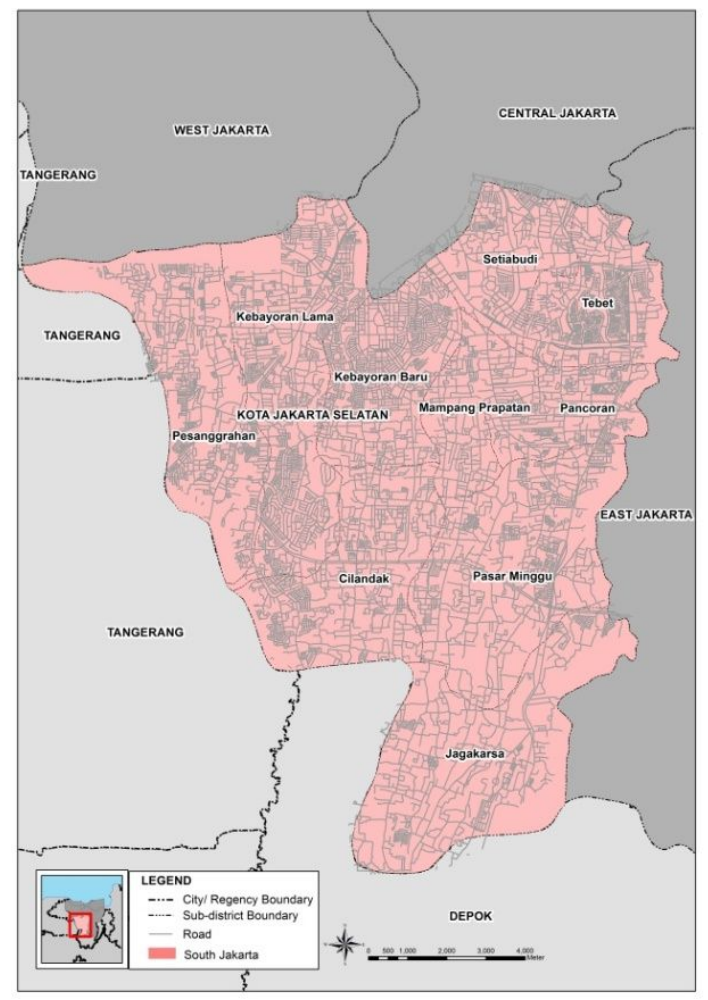

Gambar 1. Lokasi Penelitian

\section{METODE PENELITIAN}

Penelitian ini menggunakan pengambilan sampel secara acak yang menganggap semua anggota populasi memiliki kesempatan yang sama untuk dipilih sebagai anggota sampel. Penentuan jumlah sampel menggunakan Linear Time Function dengan rumus sebagai berikut:

$\mathrm{n}=\frac{\mathrm{T}-\mathrm{t}_{0}}{\mathrm{t}_{1}}$

\section{Keterangan:}

$\mathrm{n} \quad=$ Jumlah sampel

$\mathrm{T}=$ Waktu yang tersedia untuk penelitian $(14$ hari $\times 24 \mathrm{jam} / \mathrm{hari}=336 \mathrm{jam})$

$\mathrm{t}_{0}=$ Waktu pengambilan sampel (14 hari $\mathrm{x}$ $9 \mathrm{jam} / \mathrm{hari}=126 \mathrm{jam})$

$\mathrm{t}_{1}=$ Waktu yang digunakan responden untuk mengisi kuisioner (20 menit $=0,33$ jam)

$\mathrm{n}=\frac{326-126}{0,33}$

$\mathrm{n}=666,667$ sampel $=670$ sampel

Berdasarkan pergitungan, sampel dalam penelitian ini berjumlah 670 responden, yang terdiri dari 335 responden pengguna angkutan sepeda motor (ojek) berbasis online dan 335 responden pengguna angkutan mobil berbasis online.

\section{Metode Analisis}

Metode analisis yang digunakan dalam penelitian ini adalah analisis deskriptif. Analisis deskriptif digunakan untuk mendeskripsikan atau menggambarkan data yang terkumpul tanpa bermaksud membuat kesimpulan yang berlaku untuk umum atau generalisasi (Sugiyono, 2014).

Analisis deskriptif dalam penelitian ini digunakan untuk membedakan karakteristik angkutan umum berbasis online (GOJEK, Grab, dan Uber) berdasarkan aspek negara asal dan cakupan pelayanan, jenis kendaraan yang digunakan untuk pengangkutan orang, fasilitas pelayanan selai pengangkutan orang, metode pembayaran, fitur poin dan reward, jam sibuk, tarif angkutan sepeda motor dan mobil, serta biaya tambahan bila ada pembatalan. Analisis deskriptif juga digunakan untuk mendeskripsikan karakteristik angkutan umum berbasis online berupa sepeda motor dan mobil.

\section{HASIL DAN PEMBAHASAN}

Angkutan umum berbasis online merupakan sebuah inovasi dalam bidang transportasi, dengan menggabungkan sistem teknologi informasi di dalamnya. Angkutan umum berbasis online khususnya digunakan untuk angkutan sepeda motor (ojek) dan mobil (taksi) menggunakan teknologi informasi dalam sistem pengoperasiannya, yaitu melalui aplikasi yang tersedia di handphone para pelanggan. Angkutan umum berbasis online sudah menjadi salah satu transportasi pilihan bagi masyarakat Jakarta Selatan untuk melakukan perjalanan ke tempat tujuannya. 
Secara umum, perusahaan pengangkutan umum online menyelenggarakan usaha jasa pengangkutan orang dan/atau barang melalui media elektronik dengan memungut bayaran atau tarif kepada penumpang yang telah ditentukan langsung dalam aplikasi. Karakteristik lainnya, yaitu adanya sintesis antara metode pengangkutan konvensional dengan metode transaksi yang bersifat elektronik. Metode pengangkutan konvensional, yaitu terdapat waktu tunggu penumpang, sedangkan perpaduan teknologi dalam angkutan umum berbasis online, yaitu penumpang mampu melacak lokasi pengendara dengan menggunakan maps atau GPS dan juga bisa melakukan transaksi melalui online.

Terdapat dua jenis angkutan umum berbasis online, yaitu angkutan sepeda motor berbasis online (ojek) dan angkutan mobil berbasis online. Perbedaan antara kedua jenis angkutan umum berbasis online tersebut, antara lain berdasarkan tarif, waktu tempuh, serta fasilitas-fasilitas yang terdapat pada kendaraan. Sebagian besar perusahaan transportasi online menentukan tarif untuk angkutan sepeda motor berbasis online sebesar Rp 1.500 - Rp 2.500 per kilometer, sedangkan tarif untuk angkutan mobil berbasis online ditetapkan sebesar Rp 3.000 - Rp 4.250 per kilometer.

Perjalanan dengan menggunakan angkutan sepeda motor berbasis online diperkirakan akan memakan waktu yang lebih cepat dibandingkan dengan angkutan mobil, dikarenakan dengan menggunakan angkutan sepeda motor, penumpang dapat melalui jalan-jalan atau rute sempit yang tidak dapat dilalui mobil, sehingga waktu tempuhnya akan menjadi lebih cepat. Perbedaan lainnya, yaitu fasilitas moda. Fasilitas moda pada angkutan sepeda motor berbasis online, yaitu keamanan berupa tanda pengenal pengemudi dan fitur keluhan atau bantuan, keselamatan berupa alat pembatas kecepatan, kenyamanan berupa tempat meletakkan barang, serta kesetaraan berupa pelayanan prioritas dan fasilitas aksesibilitas. Fasilitas moda pada angkutan mobil berbasis online, yaitu keamanan berupa tanda pengenal pengemudi, fitur keluhan atau bantuan, dan penggunaan kaca film, keselamatan berupa ketersediaan lampu senter, ketersediaan fasilitas kesehatan, pintu keluar atau masuk, alat pembatas kecepatan, ketersediaan pegangan tangan, dan ketersediaan sabuk pengaman, kenyamanan berupa pengatur suhu ruangan, kapasitas angkut, ketersediaan tempat meletakkan barang, fasilitas kebersihan, ketersediaan sarana visual audio, dan larangan merokok, serta kersetaraan berupa pelayanan prioitas dan fasilitas aksesibilitas.

Terdapat beberapa perusahaan aplikasi penyedia transportasi berbasis online yang digunakan di Jakarta Selatan, antara lain GOJEK, Grab, dan Uber. Berikut merupakan gambaran umum dari masing-masing perusahaan dan fitur layanan yang disediakan dalam aplikasinya:

\section{GOJEK}

GOJEK berasal dari Indonesia dan didirikan pada tahun 2010 dan wilayah pelayanannya mencakup seluruh Indonesia. Fasilitas yang tersedia dalam aplikasi GOJEK untuk pengangkutan orang terdapat tiga, yaitu Go-Ride untuk angkutan sepeda motor, Go-Car untuk angkutan mobil, dan Go-Bluebird untuk taksi Bluebird. GOJEK memiliki fasilitas layanan lain selain untuk mengangkut orang, antara lain Go-Food untuk pembelian makanan, Go-Send untuk pengiriman barang, Go-Pulsa untuk pembelian pulsa, Go-Bills untuk pembayaran listrik, BPJS kesehatan, dan Google Playstore, Go-Shop untuk pembelian barang dari toko, Go-Mart untuk pembelian barang di swalayan atau supermarket, GoBox untuk penyewaan pickup, Go-Massage untuk pijat, Go-Clean untuk layanan membersihkan ruangan, Go-Glam untuk perawatan kecantikan, Go-Tix untuk pembelian tiket pertunjukan, Go-Auto untuk perawatan mobil, Go-Med untuk pengantaran obat dari apotek, dan GoBusway untuk pengantaran penumpang ke halte bus Transjakarta.

Metode pembayaran yang dapat dilakukan dalam menggunakan aplikasi GOJEK terdapat dua, antara lain dengan tunai atau menggunakan Go-Pay, yaitu layanan pembayaran online yang disediakan GOJEK. Terdapat pula fitur Go Points. Poin penggunaan GOJEK akan didapatkan jika penumpang melakukan pembayaran dengan Go-Pay. Poin-poin yang telah dikumpulkan dapat ditukarkan menjadi berbagai voucher, seperti voucher diskon ongkos perjalanan Go-Ride atau Go-Car, voucher diskon restoran, voucher diskon untuk belanja kecantikan, voucher diskon untuk pembelian elektronik, voucher diskon untuk hiburan, dan masih banyak voucher lainnya. 


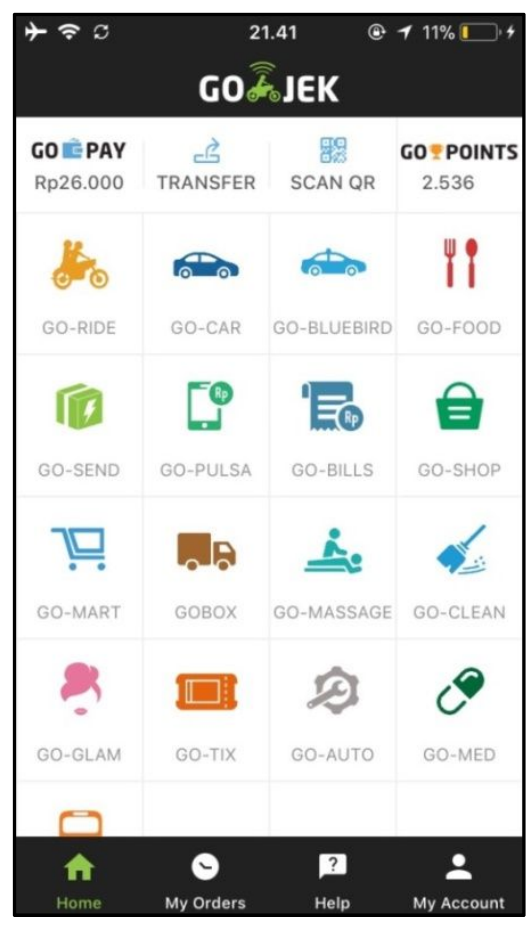

Gambar 2. Tampilan Aplikasi GoJek

Tarif untuk Go-Ride (motor) untuk jarak 0 sampai dengan 10 kilometer, yaitu $\mathrm{Rp} 1.500$ per kilometer dengan minimal pembayaran Rp 6.000, sedangkan ketika jam sibuk, tarif Go-Ride untuk jarak 0 sampai dengan 10 kilometer, yaitu $\mathrm{Rp} 2.500$ per kilometer dengan minimal pembayaran Rp 10.000 . Jika jarak melebihi 10 kilometer, maka dikenakan biaya $\mathrm{Rp} 3.000$ per kilometer untuk jam sibuk dan tidak sibuk. Tarif untuk Go-Car (mobil) untuk jarak 0 sampai dengan 2,85 kilometer, yaitu $\mathrm{Rp} 10.000$ dengan minimal pembayaran $\mathrm{Rp}$

10.000 dan jika melebih 2,85 kilometer maka dikenakan biaya $\mathrm{Rp} 3.500$ per kilometer, sedangkan ketika jam sibuk untuk jarak 0 sampai dengan 2,35 kilometer, yaitu $\mathrm{Rp} 10.000$ dengan minimal pembayaran $\mathrm{Rp}$ 10.000 dan jika melebihi 2,35 kilometer maka dikenakan biaya $\mathrm{Rp} 4.250$ per kilometer.

\section{Grab}

Grab merupakan sebuah perusahaan yang menyediakan aplikasi transportasi online yang berasal dari Malaysia. Grab tidak hanya terdapat di Indonesia, tetapi juga di beberapa negara Asia Tenggara lainnya, seperti Singapura, Malaysia, Thailand, dan Vietnam sesuai dengan visinya. Fasilitas yang tersedia pada aplikasi Grab untuk pengangkutan orang, yaitu GrabCar untuk angkutan mobil, GrabBike untuk angkutan sepeda motor, GrabHitch untuk tumpangan angkutan mobil atau motor bagi penumpang dengan tujuan yang searah, serta GrabTaxi untuk layanan taksi. Fasilitas lain selain untuk pengangkutan orang yang terdapat dalam aplikasi Grab, yaitu GrabFood untuk pembelian makanan dan GrabExpress untuk pengiriman barang.

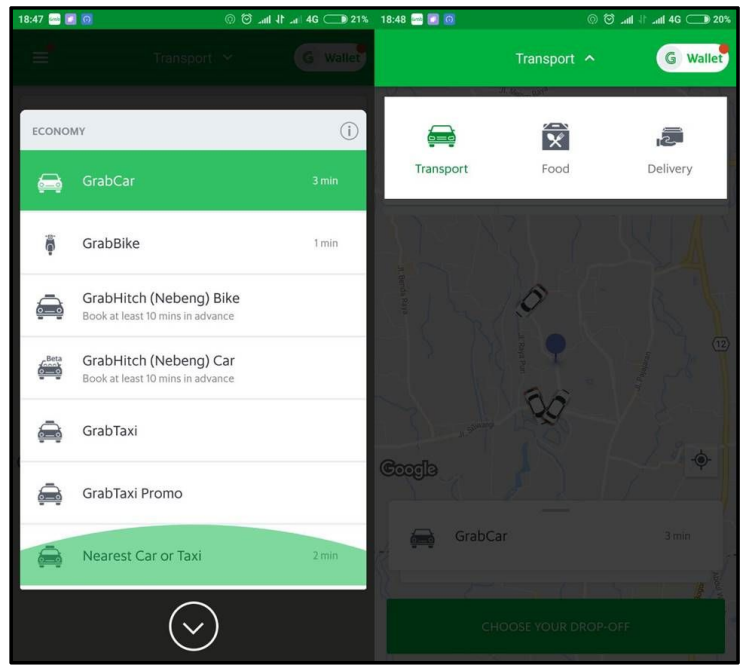

Gambar 3. Tampilan Aplikasi Grab

Metode pembayaran yang dapat dilakukan dalam penggunaan Grab terdapat dua, yaitu berupa tunai atau menggunakan Grab-Pay, yaitu layanan pembayaran online yang disediakan Grab. Terdapat fitur GrabRewards yang berisi poin dari penggunaan Grab. Poin-poin tersebut dapat ditukarkan dengan berbagai voucher, seperti voucher untuk makanan, voucher untuk diskon liburan, dan voucher lainnya. Tarif untuk GrabBike untuk jarak 0 sampai dengan 12 kilometer, yaitu Rp 1.500 per kilometer dengan minimal pembayaran $\mathrm{Rp}$ 5.000 dan jika melebihi 12 kilometer akan dikenakan biaya $\mathrm{Rp} 2.500$ per kilometer, sedangkan pada jam sibuk harga sama namun dikenakan biaya tambahan sebesar Rp 2.500. Tarif untuk GrabCar, yaitu dikenakan biaya $\mathrm{Rp} 3.500$ per kilometer dengan pembayaran minimum Rp 10.000.

3. Uber

Uber merupakan perusahaan transportasi online yang berasal dari San Francisco, California dan pelayanannya terdapat di seluruh dunia. Fasilitas layanan untuk pengangkutan orang melalui aplikasi Uber, antara lain Uber Black untuk angkutan mobil berupa mobil kelas atas, UberX untuk angkutan mobil dengan kapasitas 4 orang, UberXL untuk mobil yang lebih besar dengan kapasitas 6 orang, Uber Taxi untuk layanan taksi, Uber Motor untuk angkutan sepeda motor, dan Uber Pool untuk 
angkutan mobil yang mengantar penumpang dengan tujuan yang searah.

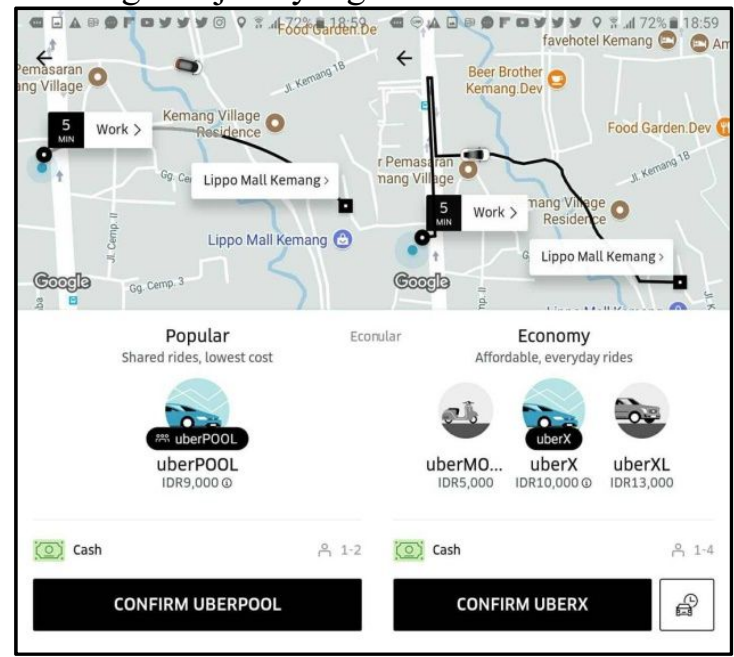

Gambar 4. Tampilan Aplikasi Uber

Berbeda dari GOJEK dan Grab, Uber tidak memiliki fasilitas layanan lain selain untuk pengangkutan orang dan metode pembayaran untuk Uber hanya bisa menggunakan uang tunai, serta tidak ada layanan poin atau reward untuk ditukarkan menjadi voucher diskon. Tarif Uber Motor untuk jarak 0 sampai dengan 12 kilometer, yaitu Rp 1.250 per kilometer dengan minimum pembayaran Rp 5.000, jika lebih dari 12 kilometer, dikenakan biaya Rp 2.000 per kilometer. Tarif untuk UberX, yaitu dikenakan biaya $\mathrm{Rp} 3.500$ per kilometer dengan pembayaran minimum sebesar $\mathrm{Rp}$ 10.000 .

Berdasarkan penjelasan di atas, perbedaan antara GoJek, Grab, dan Uber dijelaskan pada Tabel 1. berdasarkan aspek negara asal dan cakupan pelayanan, jenis kendaraan yang digunakan untuk pengangkutan orang, fasilitas pelayanan selai pengangkutan orang, metode pembayaran, fitur poin dan reward, jam sibuk, tarif angkutan sepeda motor dan mobil, serta biaya tambahan bila ada pembatalan.

Tabel 1. Perbedaan GoJek, Grab, dan Uber

\begin{tabular}{|c|c|c|c|c|}
\hline No. & $\begin{array}{c}\text { Aspek yang } \\
\text { Dibandingkan }\end{array}$ & GOJEK & Grab & Uber \\
\hline 1. & $\begin{array}{l}\text { Negara asal dan } \\
\text { cakupan pelayanan }\end{array}$ & $\begin{array}{l}\text { Berasal dari Indonesia dan } \\
\text { daerah pelayanannya seluruh } \\
\text { Indonesia }\end{array}$ & $\begin{array}{l}\text { Berasal dari Malaysia dan } \\
\text { daerah pelayanannya Malaysia, } \\
\text { Filipina, Singapura, Thailand, } \\
\text { Indonesia, dan Vietnam }\end{array}$ & $\begin{array}{l}\text { Berasal dari San Francisco, } \\
\text { California dan } \begin{array}{r}\text { daerah } \\
\text { pelayanannya } \\
\text { dunia }\end{array} \\
\end{array}$ \\
\hline 2. & $\begin{array}{l}\text { Jenis kendaraan } \\
\text { yang digunakan } \\
\text { untuk } \\
\text { pengangkutan } \\
\text { orang }\end{array}$ & $\begin{array}{l}\text { Untuk pengangkutan orang } \\
\text { terdiri dari: } \\
\text { - Go-Ride untuk angkutan } \\
\text { - } \text { sepeda motor } \\
\text { Go-Car untuk angkutan } \\
\text { mobil } \\
\text { - Go-Bluebird untuk taksi } \\
\text { Bluebird }\end{array}$ & $\begin{array}{l}\text { Untuk pengangkutan orang } \\
\text { terdiri dari: } \\
\text { - GrabCar untuk angkutan } \\
\text { mobil } \\
\text { - GrabBike untuk angkutan } \\
\text { sepeda motor } \\
\text { - GrabHitch untuk } \\
\text { tumpangan angkutan mobil } \\
\text { atau motor bagi } \\
\text { penumpang dengan tujuan } \\
\text { yang searah } \\
\text { Grab Taxi untuk taksi }\end{array}$ & $\begin{array}{l}\text { Untuk pengangkutan orang } \\
\text { terdiri dari: } \\
\text { - } \quad \text { Uber Black untuk } \\
\text { angkutan mobil } \\
\text { berupa mobil kelas } \\
\text { atas } \\
\text { - UberX untuk } \\
\text { angkutan mobil } \\
\text { dengan kapasitas } 4 \\
\text { orang } \\
\text { UberXL untuk } \\
\text { angkutan mobil } \\
\text { dengan kapasitas } 6 \\
\text { orang } \\
\text { Uber Taxi untuk taksi } \\
\text { - Uber Motor untuk } \\
\text { angkutan sepeda } \\
\text { motor } \\
\text { Uber Pool untuk } \\
\text { angkutan mobil yang } \\
\text { mengantar } \\
\text { penumpang dengan } \\
\text { tujuan yang searah }\end{array}$ \\
\hline 3. & $\begin{array}{l}\text { Fasilitas pelayanan } \\
\text { selain } \\
\text { pengangkutan } \\
\text { orang }\end{array}$ & $\begin{array}{ll}\text { - } & \text { Go-Food untuk } \\
\text { - } & \text { gembelian makanan } \\
& \text { Go-Send untuk } \\
\text { - } & \text { Go-Pulsa untuk } \\
\text { - } & \text { Gembelian pulsa } \\
\text { Go-Bills untuk } \\
\text { pembayaran listrik, BPJS } \\
\text { kesehatan, dan Google } \\
\text { Playstore } \\
\text { Go-Shop untuk } \\
\text { pembelian barang dari } \\
\text { toko }\end{array}$ & $\begin{array}{l}\text { GrabFood untuk pembelian } \\
\text { makanan } \\
\text { - } \quad \text { GrabExpress untuk } \\
\text { pengiriman barang }\end{array}$ & $\begin{array}{l}\text { Tidak tersedia fasilitas } \\
\text { pelayanan lain selain untuk } \\
\text { pengangkutan orang }\end{array}$ \\
\hline
\end{tabular}




\begin{tabular}{|c|c|c|c|c|}
\hline No. & $\begin{array}{c}\text { Aspek yang } \\
\text { Dibandingkan } \\
\end{array}$ & GOJEK & Grab & Uber \\
\hline & & $\begin{array}{ll}\text { - } & \text { Go-Mart untuk } \\
& \text { pembelian barang di } \\
\text { swalayan atau } \\
\text { supermarket } \\
\text { - } \text { Go-Box untuk } \\
\text { penyewaan pickup } \\
\text { - } \text { Go-Massage untuk pijat } \\
\text { Go-Clean untuk layanan } \\
\text { - } \text { membersihkan ruangan } \\
\text { - po-Glam untuk } \\
\text { - Go-Tix untuk pembelian } \\
\text { tiket pertunjukan } \\
\text { Go-Auto untuk } \\
\text { perawatan mobil } \\
\text { Go-Med untuk } \\
\text { pengantaran obat dari } \\
\text { apotik } \\
\text { Go-Busway untuk } \\
\text { pengantaran penumpang } \\
\text { ke halte bus Transjakarta }\end{array}$ & & \\
\hline 4. & $\begin{array}{l}\text { Metode } \\
\text { pembayaran }\end{array}$ & $\begin{array}{l}\text { Metode pembayaran dapat } \\
\text { dilakukan dengan tunai atau } \\
\text { menggunakan Go-Pay }\end{array}$ & $\begin{array}{l}\text { Metode pembayaran dapat } \\
\text { dilakukan dengan tunai atau } \\
\text { menggunakan Grab-Pay }\end{array}$ & $\begin{array}{l}\text { Metode pembayaran dapat } \\
\text { dilakukan dengan tunai } \\
\text { atau menggunakan Uber } \\
\text { Voucher }\end{array}$ \\
\hline 5. & $\begin{array}{l}\text { Fitur poin dan } \\
\text { reward }\end{array}$ & $\begin{array}{l}\text { Terdapat fitur Go Points yang } \\
\text { akan didapat jika melakukan } \\
\text { pembayaran menggunakan } \\
\text { Go-Pay dan dapat ditukar } \\
\text { menjadi berbagai voucher }\end{array}$ & $\begin{array}{l}\text { Terdapat fitur GrabRewards } \\
\text { yang didapat jika menggunakan } \\
\text { Grab-Pay dan dapat ditukar } \\
\text { menjadi berbagai voucher }\end{array}$ & $\begin{array}{l}\text { Tidak terdapat fitur point } \\
\text { atau reward }\end{array}$ \\
\hline 6. & Jam sibuk & $\begin{array}{l}\text { Jam sibuk pada GOJEK: } \\
\text { - } \quad \text { Pagi: } 06.00-09.00 \\
\text { - } \quad \text { Sore: } 16.00-19.00 \\
\end{array}$ & $\begin{array}{l}\text { Jam sibuk pada Grab: } \\
\text { - } \quad \text { Pagi: } 05.00-09.00 \\
\text { - } \quad \text { Sore: } 16.00-20.00 \\
\end{array}$ & $\begin{array}{ll}\text { Jam sibuk pada Uber: } \\
\text { - } \quad \text { Pagi: } 06.00-09.00 \\
\text { - } \quad \text { Sore: } 16.00-19.00 \\
\end{array}$ \\
\hline 7. & $\begin{array}{l}\text { Tarif angkutan } \\
\text { sepeda motor }\end{array}$ & $\begin{array}{l}\text { Tarif angkutan sepeda motor } \\
\text { (Go-Ride): } \\
\text { - } \quad 0-10 \mathrm{~km}: \mathrm{Rp} 1.500 / \mathrm{km}, \\
\text { Rp 2.500/km (jam sibuk) } \\
\text { - } \quad>10 \mathrm{~km}: \mathrm{Rp} 3.000 / \mathrm{km} \\
\text { - } \quad \text { Minimum: Rp 6.000, Rp } \\
\quad 10.000 \text { (jam sibuk) }\end{array}$ & $\begin{array}{l}\text { Tarif angkutan sepeda motor } \\
\text { (GrabBike): } \\
\text { - } \quad 0-12 \mathrm{~km}: \mathrm{Rp} 1.500 / \mathrm{km} \\
\text { - } \quad>12 \mathrm{~km}: \mathrm{Rp} 2.500 / \mathrm{km} \\
\text { - } \quad \text { Minimum: Rp } 5.000 \\
\text { Tambahan pada jam sibuk: } \\
\quad \text { Rp } 2.500\end{array}$ & $\begin{array}{l}\text { Tarif angkutan sepeda } \\
\text { motor (Uber Motor): } \\
\text { - } \quad 0-12 \mathrm{~km}: \operatorname{Rp} 1.250 / \mathrm{km} \\
\text { - } \quad>12 \mathrm{~km}: \operatorname{Rp} 2.000 / \mathrm{km} \\
\text { - } \quad \text { Minimum: Rp } 5.000\end{array}$ \\
\hline 8. & $\begin{array}{l}\text { Tarif angkutan } \\
\text { mobil }\end{array}$ & $\begin{array}{l}\text { Tarif angkutan mobil (Go- } \\
\text { Car): } \\
\text { - } \quad \text { 0-2,85 km: Rp 10.000, } \\
\quad 0-2,35 \mathrm{~km}: \text { Rp } 10.000 \\
\quad \text { (jam sibuk) } \\
\quad>2,85 \mathrm{~km}: \mathrm{Rp} 3.500 / \mathrm{km}, \\
\quad>2,35 \mathrm{~km}: \mathrm{Rp} 4.250 / \mathrm{km} \\
\quad \text { (jam sibuk) } \\
\text { - Minimum: Rp } 10.000\end{array}$ & $\begin{array}{l}\text { Tarif angkutan mobil (GrabCar): } \\
\text { - } \quad \text { Tarif per km: Rp } 3.000- \\
\text { Rp } 3.500 \\
\text { - Tarif minimum: Rp } 10.000\end{array}$ & $\begin{array}{l}\text { Tarif angkutan mobil } \\
\text { (UberX): } \\
\text { - Tarif per km: Rp } \\
\quad 3.500 \\
\text { - Minimum: Rp } 10.000\end{array}$ \\
\hline 9. & $\begin{array}{l}\text { Biaya tambahan } \\
\text { pembatalan }\end{array}$ & $\begin{array}{l}\text { Tidak terdapat biaya } \\
\text { tambahan jika melakukan } \\
\text { pembatalan }\end{array}$ & $\begin{array}{l}\text { Tidak terdapat biaya tambahan } \\
\text { jika melakukan pembatalan }\end{array}$ & $\begin{array}{l}\text { Terdapat biaya pembatalan } \\
\text { sebesar Rp } 5.000 \text { untuk } \\
\text { angkutan sepeda motor dan } \\
\text { Rp } 10.000 \text { untuk angkutan } \\
\text { mobil yang dimasukkan ke } \\
\text { dalam tarif pemesanan } \\
\text { berikutnya }\end{array}$ \\
\hline
\end{tabular}

Sumber: https://www.go-jek.com/, https://www.grab.com/id/, dan https://www.uber.com/id/

\section{SIMPULAN}

Angkutan umum berbasis online merupakan perpindahan barang atau orang dari satu tempat ke tempat lain menggunakan kendaraan yang terhubung atau terkoneksi ke jaringan internet. Pengangkutan umum online menyelenggarakan usaha jasa pengangkutan orang dan/atau barang melalui media elektronik dengan memungut bayaran atau tarif kepada penumpang yang telah ditentukan langsung dalam aplikasi. Pada pengangkutan umum online terdapat sintesis antara metode pengangkutan konvensional dengan metode transaksi yang bersifat elektronik.

Jakarta Selatan sebagai pusat permukiman dan pusat kegiatan ekonomi di DKI Jakarta, mengalami pertumbuhan penduduk setiap tahunnya yang mengakibatkan peningkatan berbagai kebutuhan, salah satunya adalah kebutuhan untuk mobilisasi yang ditunjang dengan adanya transportasi berupa kendaraan pribadi dan kendaraan umum. Seiring dengan berkembangnya teknologi, mulai diterapkan 
teknologi informasi pada angkutan umum sebagai solusi masalah kemacetan dan masalah angkutan umum konvensional. Penelitian ini bertujuan untuk mengetahui karakteristik dan perbedaan dari moda angkutan umum berbasis online di Jakarta Selatan. Analisis yang digunakan adalah analisis deskriptif. Berdasarkan hasil analisis, perbedaan karakteristik angkutan umum berbasis online tergantung pada perusahaan penyedia jasa. Perbedaan dari setiap perusahaan penyedia jasa angkutan umum berbasis online, yaitu negara asal dan cakupan layanan, jenis kendaraan yang digunakan, fasilitas pelayanan, metode pembayaran, fitur poin dan reward, jam sibuk, tarif angkutan sepeda motor dan mobil, serta biaya tambahan jika melakukan pembatalan.

\section{DAFTAR PUSTAKA}

Anindhita, W., Arisanty, M., \& Rahmawati, D. (2016). Analisis Penerapan Teknologi Komunikasi Tepat Guna pada Bisnis Transportasi Ojek Online. Prosiding Seminar Nasional INDOCOMPAC (pp. 712-714): Universitas Bakrie.

Amajida, F. D. (2016). Kreativitas Digital dalam Masyarakat Risiko Perkotaan: Studi Tentang Ojek Online “Go-Jek” di Jakarta. Jurnal Kajian Ilmu Komunikasi, 115-116.

Badan Pusat Statistik Kota Adminitstrasi Jakarta Selatan. 2016. Jakarta Selatan dalam Angka Tahun 2016. Jakarta: Badan Pusat Statistik.

Badan Pusat Statistik Kota Adminitstrasi Jakarta Selatan. 2016. Statistik Daerah Kota Jakarta Selatan Tahun 2016. Jakarta: Badan Pusat Statistik.

Badan Pusat Statistik Provinsi DKI Jakarta. 2017. Provinsi DKI Jakarta dalam Angka Tahun 2017. Jakarta: Badan Pusat Statistik.

Bahar, T., \& Tamin, O. Z. (2010). Hubungan Kualitas Pelayanan, Kepuasan, dan Loyalitas Pengguna Ojek Sepeda Motor. Jurnal Mekanika Teknik, 77-78.

Chan, A., Maharani, M., \& Tresna, P. W. (2017). Comparison of User Experience on Go-Jek and Grab Mobile Apps (Study on PT. GoJek and PT. Grab Indonesia Consumer in DKI Jakarta). Jurnal AdBispreneur, 164165.

Fatuh, M., \& Widyastuti. (2017). Pengaruh Promosi Penjualan, Perceived Ease of Use dan Perceived Usefulness Terhadap Keputusan Menggunakan Transportasi Online (Studi pada Pengguna Uber di Surabaya Pusat). Jurnal Ilmu Manajemen, 1-3.
Menteri Perhubungan Republik Indonesia, 2003. Keputusan Menteri Perhubungan Nomor: KM. 35 Tahun 2003 tentang Penyelenggaraan Angkutan Orang di Jalan dengan Kendaraan Umum. Jakarta: Kementerian Perhubungan Republik Indonesia.

Nurhidayah, F., \& Alkarim, F. (2017). Domination of Transportation Network Companies (TNCs) in Indonesia: An Indonesian Case. International Journal of Business, Economics and Law, 15-16.

Sugiyono. (2014). Metode Penelitian Kuantitatif, Kualitatif, dan Kombinasi (Mix Methods). Bandung: Alfabeta.

Wijaya, A. (2016). Aspek Hukum Bisnis Transportasi Jalan Online. Jakarta: Sinar Grafika. 